\title{
Nurse Compliance in Implementing Post Op Wound Care Standard Operating Procedures
}

\section{Suprapto Suprapto ${ }^{1}$}

1 Departemen Keperawatan, Prodi Keperawatan Politeknik Sandi Karsa

\begin{tabular}{|c|c|}
\hline Article Info & Abstract \\
\hline $\begin{array}{l}\text { Article History: } \\
\text { Submitted: Sept } 19^{\text {th }}, 2020 \\
\text { Accepted: Jan } 20^{\text {th }}, 2021 \\
\text { Published: Feb } 13^{\text {th }}, 2021 \\
\text { Keywords: } \\
\text { Length of working; } \\
\text { Knowledge; Motivation }\end{array}$ & $\begin{array}{l}\text { One of the causes of the occurrence of nosocomial infections is the } \\
\text { implementation of standard operating procedures, whether implemented } \\
\text { properly or not by nurses. Analyzing nurses' compliance in implementing } \\
\text { standard operating procedures for post-op wound care. Analytical } \\
\text { quantitative research with a cross-sectional research design. The population } \\
\text { of surgical inpatient nurses was } 32 \text { nurses, with a sample size of } 30 \text { nurses } \\
\text { with purposive sampling, analysis information used as chi-square. The } \\
\text { results of statistical tests show that there is a relationship between } \\
\text { education, knowledge, length of work, training, motivation, and nurse } \\
\text { compliance in implementing standard operating procedures for } \\
\text { postoperative wound care. That there is a relationship between education, } \\
\text { knowledge, years of service, training, and motivation with nurses' } \\
\text { compliance with the implementation of standard operating procedures for } \\
\text { post-op wound care. Improving the quality of care through efforts to develop } \\
\text { the capacity of nurses through education and training in wound care for all } \\
\text { nurses. }\end{array}$ \\
\hline
\end{tabular}

\section{PENDAHULUAN}

Infeksi nosokomial terjadi pada saat pasien dirawat inap, sebagai fasilitas layanan kesehatan memiliki peran yang penting dalam memberikan layanan kesehatan yang bermutu, efektif dan efisien serta menjamin patient safety sesuai dengan standar yang ditentukan [1]. Rumah sakit bertujuan memberi pelayanan kesehatan yaitu; promotif, preventif kuratif dan rehabilitative kepada masyarakat. Pasien, petugas kesehatan, pengunjung dan penunggu pasien beresiko terinfeksi. Oleh karena itu, pengetahuan dan sikap mencegah infeksi nosokomial akan memberikan dampak terhadap kejadian angka infeksi nosokomial [2].

Pengetahuan menurunkan terjadinya resiko infeksi nosokomial dengan penggunaan APD dengan cara menggunakan pakaian khusus perawat. Hasil penelitian membuktikan, bahwa terdapat data yang berbeda antara presentase resiko infeksi nosokomial pada perawat setelah dan sebelum menggunakan pakaian khusus perawat yaitu 95\%. Ini membuktikan bahwa terjadi peningkatan resiko yang bermakna antara penggunaan

Corresponding author:

Suprapto Suprapto

atoenurse@gmail.com

Media Keperawatan Indonesia, Vol 4 No 1, February 2021

e-ISSN: 2615-1669

ISSN: 2722-2802

DOI: $\underline{10.26714 / \mathrm{mki} .4 .1 .2021 .16-21}$ 
APD yaitu pakaian khusus perawat dengan tidak menggunakan [3]. Ketaatan perawat dalam menerapkan standar operasional prosedur merupakan ukuran keberhasilan pelayanan keperawatan luka sehingga tidak terjadi adanya infeksi diluka yang dapat mengakibatkan proses perawatan luka yang lama dan terjadi komplikasi [4].

Penilaian luka dapat dilakukan dengan pengkajian status luka dan kemajuan proses penyembuhan. Perawat dapat menggunakan sistem grade untuk melihat tingkat keparahan luka serta instrumen penilaian untuk memperkirakan proses penyembuhan luka [5]. Dalam perawatan luka pemilihan pembalut terbukti efektif dan mempersingkat masa penyembuhan luka [6]. Penelitian bertujuan menganalisa hubungan pendidikan, pengetahuan, pelatihan, lama kerja perawat kepada ketaatan melakukan standar prosedur operasional perawatan luka sesudah operasi.

\section{METODE}

Jenis penelitian desktriptif kuantitatif. Variabelnya adalah pendidikan, pengetahuan, lama kerja, pelatihan, serta ketaatan perawat dalam menerapkan standar operasional prosedur (SOP) perawatan luka Post Operasi. Populasi dalam penelitian ini adalah semua perawat RS X Kota Makassar. Sampel diambil dengan menggunakan metode purposive sampling sebanyak 30 perawat. Kuesioner terdiri atas pertanyaan pilihan tunggal dengan variabel pendidik, lama kerja, pengetahuan, motivasi dan kepatuhan terhadap penerapan Standar Operasional Prosedur (SOP). Kuesioner dibuat dalam bentuk Google Form dan telah dilakukan uji validity.

Penelitian ini telah mendapatkan persetujuan etik/izin dengan nomor surat 087/DIII/Jur.Kep/PT/SK/X/2020. Pada Google form terdapat informasi penelitian yang menjelaskan tujuan, manfaat, jaminan kerahasiaan data bagi responden dan kontak peneliti, lembar persetujuan responden, responden dapat memilih opsi setuju atau tidak, berisi kuesioner pernyataan sesuai dengan variabel. Penyebaran dan pengisian kuesioner dimulai pada tanggal 01-30 Juni 2020.

Prosedur pengumpulan data menggunakan instrumen kuisioner dengan berdasar pada daftar pustaka dengan tahapan, editing, koding serta tabulasi data. Data dianalisis dengan univariat dan bivariat serta tes statistik Chi Square dengan SPSS 21. Penelitian telah mendapat rekomendasi dan izin dari lembaga tempat penelitian serta memperhatikan informed concent, anonimity serta confidentiality. Prinsip yang digunakan dalam penelitian yaitu manfaat, menghargai hak asasi manusia dan keadilan.

\section{HASIL}

Hasil penelitian menunjukkan bahwa responden pada penelitian didominasi oleh latar belakang pendidikan diploma tiga keperawatan sebanyak $20(66,7 \%)$ orang dengan pengetahuan kurang tentang ketaatan dalam melaksanakan Standar Operasional Prosedur (SOP) perawatan luka Post Operasi. Dukungan dari manajemen rumah sakit yang diterima oleh responden dapat meningkatkan perawat dalam melaksanakan Standar Operasional Prosedur (SOP) dengan baik.

Hasil uji statistik membuktikan bahwa ada hubungan pendidikan, lama kerja, pengetahuan serta pelatihan ketaatan perawat terhadap penerapan standar operasional prosedur perawatan pada luka post pembedahan. Koefisien hubungan pendidikan 0,483 , pengetahuan 0,537 , lama kerja 0,492, pelatihan 0,573 dapat diartikan mempunyai keeratan hubungan ketaatan perawat kepada penerapan standar operasioanal prosesur( SOP) perawatan luka Post Operasi. 
Tabel 1

Analisa pendidikan, pengetahuan, lama kerja serta pelatihan dengan ketaatan perawat kepada penerapan Standar Operasional Prosedur (SOP) perawatan pada luka post operasi, n;30

\begin{tabular}{lccccc}
\hline & \multicolumn{5}{c}{ Kepatuhan } \\
\cline { 2 - 6 } Indikator & Patuh & \multicolumn{4}{c}{ Tidak patuh } \\
\cline { 2 - 6 } & $\mathrm{f}$ & $\%$ & $\mathrm{f}$ & $\%$ & \\
\hline Pendidikan & & & & & \\
$\quad$ Pernah & 7 & 70 & 3 & 30 & 0,003 \\
$\quad$ Tidak Pernah & 3 & 15 & 17 & 85 & \\
\hline Pengetahuan & & & & & \\
$\quad$ Baik & 8 & 72,7 & 3 & 27,3 & 0,000 \\
$\quad$ Kurang & 2 & 10,5 & 17 & 89,5 & \\
\hline Lama Kerja & & & & & \\
$\quad$ 5 Tahun & 9 & 60 & 6 & 40 & 0,002 \\
$\quad$ < tahun & 1 & 6,7 & 14 & 93,3 & \\
\hline Pelatihan & & & & & \\
$\quad$ Pernah & 8 & 80 & 2 & 20 & 0,000 \\
Tidak Pernah & 2 & 10 & 18 & 90 & \\
\hline
\end{tabular}

\section{PEMBAHASAN}

Hasil penelitian membuktikan ada hubungan yang berarti antara pendidikan perawat terhadap pelaksanaan standar operasional prosedur perawatan pada luka Post Operasi. Sikap seorang dipengaruhi oleh 3 aspek penting yaitu: faktor predisposisi, meliputi pengetahuan serta tindakan, budaya serta keyakinan publik, sistem adat, tingkatan pendidikan serta tingkatan sosial ekonomi. Senada dengan hasil penelitian [7] bahwa ada hubungan pendidikan dengan ketaatan terhadap pelaksanaan standar operasional prosedur (SOP) luka sesudah operasi.

Hasil penelitian ini tidak sejalan dengan hasil penelitian [8] berpendapat bahwa tingkat pendidikan tidak berpengaruh terhadap kepatuhan perawat dalam menerapkan Standar Operasioanl Prosedur (SOP) dan hasil penelitian [9] menunjukkan bahwa tidak ada hubungan yang signifikan antara tingkat Pendidikan perawat dengan prilaku kepatuhan perawat dalam melaksanakan standar operasioanl prosedur SOP. Hal ini dapat disebabkan oleh faktor karakteristik individu dan karakteristik pekerjaan.

Hasil penelitian membuktikan bahwa ada hubungan yang mempengaruhi antara pengetahuan perawat pada pelaksanaan Standar Operasional Prosedur perawatan pada luka post operasi. Perihal ini seiring dengan hasil riset. Hal ini sejalan dengan hasil penelitian [10] bahwa pengetahuan memiliki kontribusi besar dalam pengaruhi ketaatan perawat. Hasil penelitian [11] bahwa pengetahuan tentang perawatan luka memiliki hubungan dengan ketaatan perawat dalam menerapkan prosedur perawatan luka. Menurut pendapat (Suprapto,2014) bahwa terdapat hubungan antara pengetahuan perawat dalam ketaatannya melaksanakan standar operasional prosedur, sehingga dapat meningkatkan layanan kesehatan yang diberikan. Bahwa ada hubungan tingkat pengetahuan tentang perawatan luka terhadap kepatuhan perawat dalam melaksanakan prosedur tetap perawatan luka [13]. Menurut penelitian [14] bahwa terdapat hubungan yang signifikan antara pengetahuan perawat terhadap kepatuhan dalam pelaksanaan tindakan perawatan luka post-operasi. Peneliti berpendapat bahwa menjadi sangat bermakna jika pengetahuannya baik, maka ketaatan dalam penerapan Standar Operasional Prosedur (SOP) akan meningkat.

Hasil penelitian menunjukkan bahwa terdapat hubungan yang bermakna antara lama kerja perawat terhadap pelaksanaan standar operasional prosedur perawatan pada luka post operasi. Hasil penelitian ini tidak sejalan dengan hasil penelitian [15] bahwa tidak ada hubungan antara lama kerja dengan ketaatan perawat dalam melaksanakan standar operasional prosedur. Namun menurut [7] kepatuhan terhadap penerapan standar operasional prosedur luka pascaoperasi dipengaruhi oleh pendidikan, pengetahuan, lama kerja, pelatihan dan motivasi. Menurut (Suprapto, 2020) bahwa pengaruh usia responden, pendidikan terakhir dan lama kerja serta 
ketersediaan alat pelindung diri dapat mempengaruhi dalam pemberian pelayanan kesehatan. Ketaatan perawat dalam melaksanakan prosedur perawatan luka dapat diukur berdasarkan pada evaluasi dan pengawasan tindakan prosedur tersebut. Hasil penelitian [17] menyimpulkan bahwa lama bekerja terhadap motivasi perawat dalam menerapkan Standar Operasional Prosedur (SOP). Seorang perawat sebagai aktor dalam pelaksanaan tindakan keperawatan harus memiliki pengalaman kerja dalam menerapkan standar dengan baik agar melaksanakan Standar Operasional Prosedur (SOP) asuhan keperawatan secara baik dan benar. Namun tidak sejalan dengan hasil penelitian [18] bahwa tidak ada hubungan antara lama kerja dengan ketaatan perawat dalam penerapan SOP. Ketaatan terhadap Standar Operasional Prosedur (SOP) merupakan bagian penting dalam manajemen keamanan pasien, sehingga dibutuhkan petugas yang profesional serta terampil dalam melaksanakannya.

Hasil penelitian menunjukkan terdapat hubungan yang bermakna antara pelatihan perawat terhadap pelaksanaan standar operasional prosedur perawatan pada luka post operasi. Menurut hasil penelitian [19] pelatihan memberikan dampak pada pengetahuan perawat terhadap penerapan Standar Operasional Prodesur( SOP). Menurut [20] berpendapat bahwa pelatihan tentang Standar Operasional Prosedur dapat meningkatkan mutu pelayanan rumah sakit. Hasil penelitian [7] bahwa ada hubungan pelatihan dengan ketaatan terhadap pelaksanaan( SOP) luka sesudah pembedahan maka, terjadinya infeksi nosokomial bisa diatasi dengan pelaksanaan Standar Operasional Prosedur yang betul- betul dilaksanakan dengan baik dan benar oleh petugas kesehatan.

Menurut hasil penelitian [21] berpendapat bahwa ada hubungan antara ketaatan perawat kepada penerapan standar operasional prosedur rawat luka dengan prosedur pengobatan luka sesudah operasi. Hasil penelitian ini tidak sejalan dengan hasil penelitian [22] bahwa tingkat kepatuhan perawat dalam pelaksanaan protap perawatan luka mayoritas patuh, kepatuhan perawat dalam pelaksanaan prosedur tetap rawat luka dengan infeksi luka pasca operasi sectio caesarea tidak ada hubungan. Menurut [23] bahwa dalam proses penyembuhan luka post operasi dipengaruhi oleh faktor internal dan faktor eksternal. Selain itu perawatan luka post operasi dapat berkualitas jika dalam tindakannya mengacu pada prosedur tetap ada. Menurut [24] bahwa motivasi dapat mendorong individu dalam bekerja karena motivasi merupakan kekuatan individu untuk melaksanakan pekerjaan sesuai protap yang telah ditetapkan. Menurut hasil penelitian [25] jumlah pasien dengan kegiatan operasi yang semakin bertambah dari tahun ketahun bisa pengaruhi kenaikan komplikasi setelah pembedahan semacam akibat terjadinya infeksi luka operasi( ILO) infeksi nosokomial. Peran tenaga kesehatan spesialnya perawat di ruang operasi terhadap prinsip steril dalam melaksanakan prosedur perawatan luka post op laparatomi yang merupakan sesuatu kegiatan yang amat berarti dicoba buat menghindari terjadinya infeksi.

Kebahagiaan pasien merupakan perasaan suka maupun kecewa timbul sesudah membandingkan antara hasil dari sesuatu pelayanan telah sesuai maupun belum sesuai dengan keinginan yang di milikinya [26]. Menurut pendapat [27] bahwa budaya keselamatan pasien sangat dibutuhkan untuk meningkatkan keselamatan pasien di rumah sakit. Sehingga akan meningkatkan akuntabilitas terhadap keselamatan pasien yaitu dengan membuat peraturan-peraturan rumah sakit yang membuat kualitas keselamatan pasien meningkat dan angka kejadian kesalahan di rumah sakit dalam melakukan pengendalian dan pencegahan infeksi.

Infeksi situs bedah adalah masalah yang umum dan mahal, memperpanjang rawat 
inap dan meningkatkan masuk kembali. Kepatuhan terhadap langkah-langkah proses pengendalian infeksi yang terkenal belum dikaitkan dengan penurunan substansial, yang dapat dicegah terus mengakibatkan bahaya bagi pasien dan peningkatan biaya perawatan kesehatan dalam skala luas. Dalam memberikan layanan keperawatan terdapatnya standar operasional prosedur telah ditetapkan. Disiplin perawat dalam menerapakan standar operasional prosedur diharapkan dapat menunjang mencapai asuhan keperawatan yang bermutu.

\section{SIMPULAN}

Bahwa faktor pendidikan, pengetahuan, pelatihan, dan lama kerja merupakan hal yang penting bagi perawat dalam kepatuhan melaksanakan standar operasional prosedur rawat luka pasca operasi.

\section{UCAPAN TERIMAKASIH}

Penulis ingin mengucapkan terima kasih kepada teman sejawat perawat dan pasien pasca operasi atas partisipasinya dalam penelitian ini.

\section{REFERENSI}

[1] Riani R, Syafriani S. Hubungan Antara Motivasi Dengan Kepatuhan Perawat Melaksanakan Handhygiene Sebagai Tindakan Pencegahan Infeksi Nosokomial Di Ruang Rawat Inap Rumah Sakit Ah Tahun 2019. J Ners 2019;3:49-59.

[2] Mariana ER, Zainab Z, Kholik S. Hubungan pengetahuan tentang infeksi nosokomial dengan sikap mencegah infeksi nosokomial pada keluarga pasien di ruang penyakit dalam RSUD Ratu Zalecha Martapura. J Skala Kesehat 2015;6.

[3] Amrullah AA. Gambaran Risiko Infeksi Nosokomial pada Perawat di Ruang Rawat Inap RSUD Haji Makassar Tahun 20162017.

[4] Munandar I. Kepatuhan Perawat dalam Pelaksanaan Standar Operasional Prosedur (SOP) Perawatan Luka dengan Kejadian Infeksi Luka Operasi Post Sectio Caesaria. J
Ilm Ilmu Keperawatan Indones 2018;8:4228.

[5] Rasyid N, Yusuf S, Tahir T. Pengkajian Luka Kaki Diabetes. J Luka Indones 2018;4:12337.

[6] Divandra C. Madu Sebagai Dressing Pada Penyembuhan Ulkus Diabetikum. J Ilm Kesehat Sandi Husada 2020;11. https://doi.org/10.35816/jiskh.v11i1.345.

[7] Laksono A, Purwanti SKM. Faktor-Faktor yang Berhubungan dengan Kepatuhan Petugas Keperawatan terhadap Pelaksanaan Standar Prosedur Operasional Rawat Luka Paska Operasi (Post Op) di Ruang Rawat Inap Khusus Bedah RSUD Kota Madiun 2018.

[8] Nazvia N, Loekqijana A, Kurniawati J. Faktor yang mempengaruhi kepatuhan pelaksanaan SOP asuhan keperawatan di ICU-ICCU RSUD Gambiran Kota Kediri. J Kedokt Brawijaya 2014;28:21-5.

[9] Pagala I, Shaluhiyah Z, Widjasena B. Perilaku Kepatuhan Perawat Melaksanakan SOP Terhadap Kejadian Keselamatan Pasien di Rumah Sakit X Kendari. J Promosi Kesehat Indones 2017;12:138-49.

[10] Saodah S. Knowledge of Guideline VAP Bundle Improves Nurse Compliance Levels in Preventing Associated Pneumonia (VAP) Ventilation in the Intensive Care Unit. Media Keperawatan Indones 2019;2:113. https://doi.org/10.26714/mki.2.3.2019.113 -120 .

[11] Yulianto A. Hubungan tingkat pengetahuan tentang perawatan luka dengan kepatuhan perawat dalam melaksanakan prosedur perawatan luka. J Ilm Kesehat 2016;5.

[12] Suprapto SS. Hubungan Antara Tingkat Pengetahuan Perawat Tentang Pemasangan Infus Dengan Kepatuhan Pelaksanaan Protap Pemasangan Infus Di Instalasi Gawat Darurat Rs Tk Ii Pelamonia Makassar. J 03 2014;1:125.

[13] Sari L, Wiryansyah OA. Hubungan Tingkat Pengetahuan Perawatan Luka Terhadap Kepatuhan Perawat Dalam Prosedur Perawatan Luka. J Kesehat Dan Pembang 2020;10:44-55.

[14] Yanti IRARMEI. Hubungan Pengetahuan Perawat Dengan Kepatuhan Perawat Dalam Pelaksanaan Tindakan Perawatan Luka PostOperasi Di Rumah Sakit Santa Elisabeth Medan 2018.

[15] Moniung F, Rompas S, Lolong J. Hubungan lama kerja dengan kepatuhan perawat dalam melaksanakan SOP pemasangan infus di RSU GMIM pancaran kasih Manado. J 


\section{KEPERAWATAN 2016;4.}

[16] Suprapto S. Nurse Compliance using Basic Personal Protective Equipment in Providing Health Services Nursing Actions. Int J Med Public Heal 2020;10:119-21. https://doi.org/10.5530/ijmedph.2020.3.25

[17] Dewi ES, Ismahmudi R. Faktor-Faktor yang Berhubungan dengan Motivasi Perawat dalam Menerapkan Standar Operasional Prosedur (SOP) Asuhan Keperawatan di RSJD Atma Husada Mahakam Samarinda Tahun 20162016.

[18] Widyastuti R. Hubungan Lama Kerja Dengan Kepatuhan Perawat Dalam Pelaksanaan Standar Operasional Prosedur Triage Di Instalasi Gawat Darurat Rumah Sakit Umum Daerah Wates kulon Progo 2017.

[19] Sucipto MA. Pengaruh Pelatihan Pemasangan Infus Pada Perawat Terhadap Kepatuhan Pemasangan Infus Sesuai Dengan Standar Operasional Prosedur (Di Rumah Sakit Graha Kedoya Jakarta). UEU Digital Repository, 2014.

[20] Amalia A. Hubungan Perilaku Perawat Terhadap Pelaksanaan Standar Operasional Prosedur Dalam Pemasangan Ivfd Diruang Rawat Inap Rumah Sakit Pelabuhan Palembang Tahun 2014. Masker Med 2016;4:71-8.

[21] Suhada M. Hubungan Antara Tingkat Kepatuhan Perawat Terhadap SOP (Standar
Operasional Prosedur) Perawatan Luka Dengan Proses Penyembuhan Luka Pasien Pascabedah Di RSUD dr. H. Andi Abdurrahman Noor. J Keperawatan Muhammadiyah 2019;4. https://doi.org/10.30651/jkm.v4i1.2105.

[22] Gultom H. Hubungankepatuhan Perawat Dalampelaksanaan Protap Perawatan Luka Dengan Kejadian Infeksipost Operasi Sectio Caesarea Di Ruang Rb/Vk Lantai 4 Rsu Sari Mutiara Medan Tahun 20152015.

[23] Daryanti HK. Faktor-faktor yang mempengaruhi Kepatuhan Perawat Dalam Penerapan Protap Perawatan Luka Post Operasi di Ruang Cendana RSUD Dr. Moewardi Surakarta 2008.

[24] Busro M. Teori-teori manajemen sumber daya manusia. Prenada Media; 2018.

[25] Novalin Kalilo I. Hubungan Kepatuhan Perawat Terhadap Prinsip Steril Perawatan Luka Dengan Kejadian Infeksi Pada Luka Post Op Laparatomi Di Bangsal Bedah RSUD Wates 2017.

[26] Sulistyorini S. Hubungan kepatuhan perawat dalam menerapkan Standar Operasional Prosedur (SOP) perawatan luka dengan tingkat kepuasan pasien Luka Gangren di RSK Budi Rahayu Blitar 2019.

[27] Ayunda T. Kebijakan Pencegahan Dan Pengendalian Infeksi Untuk Meningkatkan Standar Akriditasi Rumah Sakit 2019. 